\title{
The Effect of Education and Job Training on Increasing Employee Productivity at PT. Sagami Indonesia
}

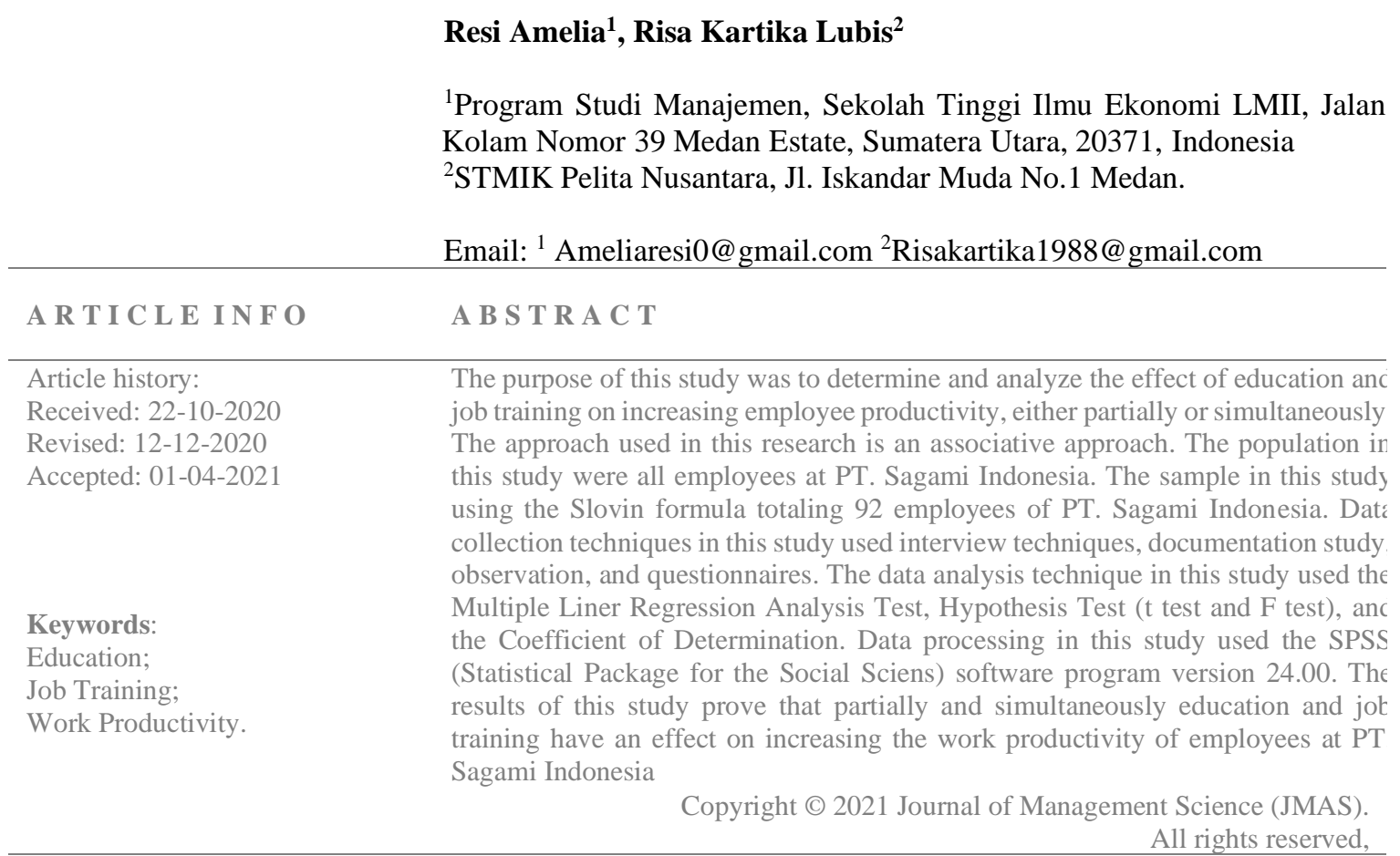

\section{Introduction}

In line with the increasingly global development of the business world, the management of an organization must be carried out professionally and productively, so that the organization can continue to survive and continue to develop along with the times. In every company, human resources (HR) are the most important assets that must be maintained by the company. In the process of achieving the goals of a company, it is strongly influenced by quality resources to produce goods or services. Training is one of the efforts made by companies to improve the quality of human resources in the world of work. Training is a process to shape and equip employees by adding to their skills, abilities, knowledge and behavior. [4] In the context of human resource development, education and training are efforts to develop human resources, especially to develop intellectual abilities and human personality. [5]. Based on the background of the problem above, the authors are interested in conducting research on the effect of education and job training on increasing employee productivity at PT.Sagami Indonesia.

\section{Method}

This type of research is quantitative research. This study aims to the effect of education and job training on the increase in productivity of employees at PT.Sagami Indonesia. The data instrument test conducted in this study was the validity and reliability test. The analysis used in this research is to use multiple linear regression test along with the classical assumption test. The population in this study were all customers of the Medan branch of Indomaret jln industry. The sample in this study were 100 people. The sampling method used was a random sampling method

\section{Results and discussion}

\subsection{Results}

\section{a. Data Validity Test}

The validity test is used by correlating the total factor score with the total score. If the correlation of each factor ( $\mathrm{r}$ count) is positive and the magnitude is 0.360 and above, the factor is a strong construct so it can be concluded that the instrument has good construction validity. 
Table 1

Validity Test Results

\begin{tabular}{|c|c|c|}
\hline Statement Items & Probability & Information \\
\hline Work Productivity Variable (Y) & $0.000<0.05$ & Valid \\
\hline Y1-Y12 & Probability & Information \\
\hline Statement Items & $0.000<0.05$ & Valid \\
\hline Educational Variable (X1) & Probability & Information \\
\hline $\mathrm{X} 1-\mathrm{X} 10$ & $0.000<0,05$ & Valid \\
\hline
\end{tabular}

From the table above the items of the questionnaire, namely the results of the validity test, show that the Pearson correlation value of all variables is greater than 0.3 , thus all items of the measurement instrument can be said to be valid.

\section{b. Reliability Test}

The results of reliability testing in the table above indicate that the three variables have a coefficient of alpha $(\alpha)>0.6$ so that it can be said that the questionnaire compiled is reliable or reliable as a data collection tool in this study.

Table 2

Reliability Test Results

\begin{tabular}{lccc}
\hline Variable & Cronbach Alpha & R Tabel & Information \\
\hline Work productivity & 0.889 & & Reliabel \\
Education & 0.890 & 0,60 & Reliabel \\
Work training & 0.813 & & Reliabel \\
\hline \multicolumn{1}{c}{ Source: Primary data processed, 2020} & &
\end{tabular}

The results of reliability testing in the table above indicate that the three variables have a coefficient of alpha $(\alpha)>0.60$ so that it can be said that the questionnaire compiled is reliable or reliable as a data collection tool in this study.

c. Multiple Linear Regression Test Results

Multiple linear regression analysis aims to measure the strength of the relationship between two or more variables, it also shows the direction of the relationship between the dependent variable and the independent variable. This study uses multiple linear regression equations because it has more than one independent variable. Following are the results of data processing using SPSS 22.

Table 3

Linear Regression Test Results Coefficients $^{\mathbf{a}}$

\begin{tabular}{|c|c|c|c|c|c|c|}
\hline \multicolumn{7}{|c|}{ Coefficients $^{\mathbf{a}}$} \\
\hline \multirow[b]{2}{*}{ Model } & \multicolumn{2}{|c|}{ Unstandardized Coefficients } & \multicolumn{2}{|c|}{ Standardized Coefficients } & \multirow[b]{2}{*}{$\mathrm{t}$} & \multirow[b]{2}{*}{ Sig. } \\
\hline & $\mathrm{B}$ & Std. Error & Beta & & & \\
\hline 1 (Constant) & 1,699 & 2,155 & & & ,789 & ,432 \\
\hline Education & ,443 &, 097 & & ,289 & 4,589 &, 000 \\
\hline Work Training & ,887 &, 082 & & 684 & 10,875 & 000 \\
\hline a. Dependent Vari & ble: Work 1 & ing & & & & \\
\hline
\end{tabular}

These results are entered into the multiple linear regression equation so that the following equation is known:

So the above equation means if:

$$
\mathrm{Y}=1.699+0.4431+0.8872
$$

a) A constant of 1.699 shows that if all the independent variables of education and job training are assumed to be zero, then the value of work productivity is 1.699 .

b) The education regression coefficient value of 0.443 indicates that if the value of the education variable is at least one unit, then work productivity increases by 0.443 units, assuming the other independent variables are zero.

The regression coefficient value for job training is 0.887 indicating that if the value of the job training variable is at least one unit, then work productivity increases by 0.887 units, assuming the other independent variables are zero.

d. Partial Test Result (t test)

The $t$ test is one of the hypothesis tests in multiple linear regression analysis research, the $t$ test aims to determine whether the independent variable $(\mathrm{X})$ partially affects the dependent variable $(\mathrm{Y})$.. 
Table 4

T Test Results

\begin{tabular}{|c|c|c|c|c|c|c|}
\hline \multicolumn{7}{|c|}{ Coefficients $^{\mathrm{a}}$} \\
\hline \multirow{2}{*}{\multicolumn{2}{|c|}{ Model }} & \multicolumn{2}{|c|}{ Unstandardized Coefficients } & \multirow{2}{*}{$\begin{array}{c}\text { Standardized Coefficients } \\
\text { Beta }\end{array}$} & \multirow[b]{2}{*}{$t$} & \multirow[b]{2}{*}{ Sig. } \\
\hline & & B & Std. Error & & & \\
\hline 1 & (Constant) & 1,699 & 2,155 & & ,789 & 432 \\
\hline & Education & ,443 & ,097 & 285 & 4,589 & 000 \\
\hline & Work Training & ,887 & 082 &, 68 & 10,875 & 000 \\
\hline
\end{tabular}

The results of statistical testing in the table above can be explained as follows:

a) Effect of Education (X1) on Work Productivity (Y)

The $\mathrm{t}$-count value for the education variable is 4.589 and the $\mathrm{t}$-table with $\alpha=5 \%$ is known to be 1.987, thus tcount is greater than t-table and the significant value of education is $0.000<0.05$, meaning that from these results it can be concluded that $\mathrm{H} 0$ is rejected (Ha accepted) indicates that education has a significant effect. on the work productivity of PT. Sagami Indonesia.

b) Effect of Job Training (X2) on Work Productivity (Y)

The t-count value for the job training variable is 10.875 and the t-table with $\alpha=5 \%$ is known to be 1.987, thus tcount is greater than t-table and the significant value of job training is 0.000 $<0.05$, meaning that from these results it can be concluded that $\mathrm{H} 0$ is rejected (Ha is accepted) indicates that training work has a significant effect on the work productivity of employees of PT. Sagami Indonesia

\section{e. Simultaneous Test Results (Test F)}

\begin{tabular}{|c|c|c|c|c|c|c|}
\hline \multicolumn{7}{|c|}{$\begin{array}{c}\text { Table } 5 \\
\text { F Test Results }\end{array}$} \\
\hline \multicolumn{7}{|c|}{ ANOVA $^{a}$} \\
\hline Model & & Sum of Squares & df & Mean Square & $\mathrm{F}$ & Sig. \\
\hline \multirow[t]{3}{*}{1} & Regression & 2301,554 & 2 & 1150,777 & 261,440 &, $000^{\mathrm{b}}$ \\
\hline & Residual & 391,751 & 89 & 4,402 & & \\
\hline & Total & 2693,304 & 91 & & & \\
\hline
\end{tabular}

Source: Primary data processed, 2020

From the results above, it can be seen that the F_count value is 261,440 with a significant level of 0.000 . While the value of $\mathrm{F}$ table is known to be 3.10 . based on these results it can be seen that f_count> ftable $(261.440>3.10)$ means that $H_{-}$0 is rejected. So it can be concluded that the variables of education and job training together have a significant effect on the work productivity of employees at PT. Sagami Indonesia.

\section{f. Coefficient of Determination (R2)}

The coefficient of determination is carried out to test the influence of the variable product quality and work experience $(\mathrm{X})$ on purchasing decisions $(\mathrm{Y})$.

Table 6

Coefficient of Determination (R2) Results

\begin{tabular}{|l|l|l|l|l|}
\hline Model & R & R Square & $\begin{array}{l}\text { Adjusted R } \\
\text { Square }\end{array}$ & $\begin{array}{l}\text { Std. Error of the } \\
\text { Estimate }\end{array}$ \\
\hline 1 &, $714^{\mathrm{a}}$ &, 510 &, 500 & 4,296 \\
\hline
\end{tabular}

Source: Primary data processed, 2020

Based on the table above, it can be seen that the value of the R square is 0.855 which means $85.5 \%$ and this indicates that the variables of education and job training are $85.5 \%$ to influence work productivity variables. Furthermore, the difference is $100 \%-85.5 \%=14.5 \%$. this shows that $14.5 \%$ is another variable that does not contribute to work productivity research.

\subsection{Discussion}

\section{a. The Effect of Education on Work Productivity}

Based on the research obtained regarding the effect of education on employee work productivity at PT. Sagami Indonesia, the results of the hypothesis test partially show that the t_count value for the education variable is 4.589 and the t-table with $\alpha=5 \%$ is known to be 1.987 , thus the tcount is greater than $t$ table and the significant value of education is $0.000<0.05$, meaning that the conclusion is that $\mathrm{H} 0$ is rejected. (Ha accepted) indicates that education has a significant effect on the work productivity 
of PT. Sagami Indonesia. This shows that education is able to increase the work productivity of employees at PT. Sagami Indonesia, where with the increase in employee education, employee productivity will increase, employees with a high level of education and in accordance with the position they hold, the productivity of these employees will increase.

b. The Effect of Job Training on Work Productivity

Based on the research obtained regarding the effect of job training on employee work productivity at PT. Sagami Indonesia results of hypothesis testing partially show that the value of tcount for the job training variable is 10.875 and the ttable with $\alpha=5 \%$ is known to be 1.987 , thus tcount is greater than ttable and the significant value of job training is $0.000<0.05$, meaning that the results are concluded that $\mathrm{H} 0$ rejected ( $\mathrm{Ha}$ accepted) indicates that job training has a significant effect on the work productivity of PT. Sagami Indonesia.

This shows that job training is able to increase the work productivity of employees at PT. Sagami Indonesia, where the increasing training provided by the company for employees who support the work of these employees, the productivity of these employees will increase.

c. Effect of Education and Job Training on Work Productivity

Based on the research obtained regarding the effect of education and job training on the work productivity of employees at PT. Sagami Indonesia, the results of simultaneous hypothesis testing show that the value of $F_{-}$count for the job training variable is 10.875 and the $F$ table with $\alpha=5 \%$ is known to be 1.987, thus $\mathrm{F}_{\text {_count }}$ is greater than $\mathrm{F}$ table and the significant value of job training is $0.000<0.05$, meaning that the results are concluded that $\mathrm{H} 0$ rejected (Ha accepted) indicates that job training has a significant effect on the work productivity of PT. Sagami Indonesia.

This shows that education and job training together can increase the work productivity of employees at PT. Sagami Indonesia where with the higher education of each employee and according to the position of the employee and followed by training that the company verifies for these employees to support work, the productivity of these employees will increase.

\section{Conclusion}

The results of the study led to the following conclusions:

a. Partially education has a significant effect on the work productivity of employees at PT. Sagami Indonesia where the value of $t$ count 4.589> $t$ table 1.987 and a significant value of $0.000<0.05$ so that $\mathrm{HO}$ is rejected (Ha is accepted)

b. Partially job training has a significant effect on employee work productivity at PT. Sagami Indonesia where the value of $t$ count $10.875>t$ table 1.987 and a significant value of $0.000<0.05$ so that $\mathrm{H} 0$ is rejected (Ha is accepted)

c. Simultaneously education and job training together have a significant effect on employee work productivity at PT. Sagami Indonesia where the value of F_count 10.875> F table 1.987 and a significant value of $0.000<0.05$ so that $\mathrm{H} 0$ is rejected ( $\mathrm{Ha}$ is accepted).

\section{Refrence}

[1] Arikunto, S. (2013). Research Procedure A Practical Approach. Jakarta: PT.Rineka Cipta.

[2] Arikunto, S. (2016). Research Management. Jakarta: PT.Rineka Cipta.

[3] Barnadib, S. I. (2013). Introduction to Systematic Education. Yogyakarta: Waves.

[4] Dini Muammar Gaddafi. (2016). The Effect of Training on Work Productivity of CV. Sinar Utama Group Center In Samarinda. Journal of Business Administration, 04 (01), 36-46.

[5] Sutrisno, Edi. (2016). Human Resource Management First Edition. Jakarta: Prenadamedia Group.

[6] Ema Nurzainul Hakimah. (2014). The Effect of the Implementation of Education and Training Programs for Employees to Increase Work Productivity at "UD.Gakris" Kediri. Journal of Economics and Business Research, 01 (02), 27-39.

[7] Ihsan, F. (2011). Education Basics. Jakarta: PT.Rineka Cipta.

[8] Hasbullah. (2015). Basics of Education. Jakrta: PT. RajaGrafindo Persada.

[9] Hasibuan, Malayu. (2010). Human Resource Management. Bandung: PT. Rosdakarya youth.

[10] Herawati, N., \& Sasana, H. (2013). Analysis of the Influence of Education, Wages, Work Experience, Gender and Age on the Productivity of Tegal City SHUTLLECOCK Industrial Workforce. Journal of Economics, 02 (04), 1-8.

[11] Handoko, H. T. (2015). Management Edition 2. Yogyakarta: BPFE

[12] Ghozali, I. (2013). Multivariate Analysis Application with SPSS program. Semarang: Diponegoro University Publishing Agency.

[13] Komarudin. (2018). Effect of Training and Motivation on Employee Productivity of PT. Lion Mentari Airlines Soekarno Hatta Airport Cengkareng. Forkamma Management Scientific Journal, 01 (02), 128-145. 
[14] Manullang, M. (2012). Human Resource Management. Bandung: Citapustaka Media Perintis.

[15] Mangkunegara, (2017). Company Human Resource Management. Bandung PT. Rosdakarya youth.

[16] Mapparenta. (2011). The Influence of Education, Training and Work Discipline on Work Productivity of Regional Secretariat Employees in East Halmahera Regency, North Maluku Province. Journal of Management Applications, 09 (03), 1043-1049.

[17] Martini, K. W., Metera, G. M., \& Jiwa, D. N. A. (2018). Level of Education, Training and Employee Productivity of Buleleng District General Hospital (RSUD) Human Resources (HR) Unit Work Unit. Journal of Management, 05 (01), 1-12.

[18] Maulana Setihada. (2014). The Influence of Education and Motivation on Employee Productivity at PDAM Kota Samarinda in 2012. Journal of Business Administration, 02 (01), 41-50.

[19] Maunah, B. (2009). Education Science. Yogyakarta: TERAS.

[20] Nora Anisa Br Sinulingga. (2014). The Effect of Workforce Education and Training on Increasing Employee Productivity of PT. Shamrock Corpora. Mantik Penusa's Journal, 15 (01), 2088-3943.

[21] Prabowo, B. P. S., Lengkong, V. P. K., \& Dotulong, L. O. H. (2016). The Effect of Educational Level and Placement on Employee Productivity at PT. Indonesian Ship Industry, Bitung. Periodic Scientific Journal of Efficiency, 16 (04), $1-14$.

[22] Rivai, V. (2012) MSDM For Companies, Jakarta: PT. Raja Grafindo Persada.

[23] Sudibyo Budi Utomo. (2018). The Influence of Workforce Education and Training on Work Productivity of the Cashier Section Employees at the Yogya Department Store in Majalengka Regency. Indonesian Scientific Journal, 03 (06), 83-97.

[24] Susanto, A.B. (2011). Management For Everyone Human Capital. Jakarta: Erlangga.

[25] Sugiyono. (2018). Business Research Methods. Bandung: Alfabeta, CV.

[26] Soewadji, J. (2012). Introduction to Research Methodology. Jakarta: Mitra Wacana Media.

[27] Sri Hardiati. (2011). Human Resource Management. Jakarta: RI State Administration Institute.

[28] Trianto, F., Nurhajati, \& Wahono, B. (2015). Analysis of the Influence of Education, Incentives and Social Security on Labor Productivity (Study in the Freight Forwarding Company PT. KING STONE Malang. Journal of Management Research, 1-12. U.U R.I No. 20 Tahun (2003). (2013).

[29] SISDIKNAS and Government Regulation of the Republic of Indonesia in 2013 concerning National Standards for Education and Compulsory Education. In Citra Umbara.

[30] Umi Nur Cholis. (2013). The Effect of Employee Training on Work Productivity at PT. Pacific Indo Packing Surabaya. Journal of Office Administration, 01 (03), 1-17.

[31] Yussi Rapareni. (2013). The Effect of Education and Training on Productivity of Teachers at the Jihadiyah Foundation in Palembang. Journal of Economics and Accounting Information (JENIUS), 03 (03), 216-229. 